\title{
Introduction
}

\author{
Rachida Chih, David Jordan, and Stefan Reichmuth
}

This second volume of the Presence of the Prophet series engages with the task to analyse the significance of the figure of the Prophet in the early modern and modern periods for questions of power, authority, and individual and collective self-empowerment. ${ }^{1}$ This includes rulers, scholars, and activists who have claimed his material or spiritual heritage as leaders or saviours. The chapters of this volume go back to a workshop in Bochum ("The Prophet and the Modern State" - May 2018) ${ }^{2}$ and to a colloquium held in Marrakesh ("The Prophet and His Heritage" - November 2018) ${ }^{3}$ where they were presented and discussed for the first time.

The historiographical and chronological framework of the collection starts out with the early modern Muslim empires and regional states in the period between approximately 1450 and 1700 , followed by a focus on the age of transformations and revolutionary ruptures of the late eighteenth and early nineteenth centuries. It then shifts to the formation of Muslim nation-states and their ideologies since the late nineteenth and early twentieth centuries, and finally to the thoroughgoing changes that Muslim states and societies have faced from the late 1970s onwards until the present.

The beliefs, practices, and ideologies connected with the figure of the Prophet generally followed long-term developments and were not automatically subject to the sometimes rapid changes and upheavals of political history. But they nevertheless have remained sensitive to the transformations in the political sphere, and to the crises of conscience, legitimation, and power that often go along with them. In such times of crisis, which may also involve recognised or self-acclaimed inheritors of the Prophetic legacy, it is particularly difficult to maintain a distinction between the time frame of a religious or intellectual "history of Islam", on the one hand, and that of the political "history

1 The series is the product of a joint French-German research project titled "The Presence of the Prophet: Muhammad in the Mirror of His Community in Early Modern and Modern Islam". For the website of this joint ANR-DFG project (2017-20), see https ://prophet.hypoth eses.org.

2 https://prophet.hypotheses.org/the-prophet-and-the-modern-state.

3 https://prophet.hypotheses.org/international-conference-presence-of-the-prophet-and -his-heritage-marrakesh-4-7-november-2018. 
of the Muslims", on the other, and to restrict attention only to one side of the historical process. ${ }^{4}$

The thematic set-up of this volume roughly follows a chronological order. It begins (Part 1) with the role of the Prophet in the imperial piety promulgated by the Ottoman court, and on the Prophetic model and its significance for the revolutionary Islamic movements of the eighteenth and early nineteenth centuries, before and during European commercial and military encroachment. Part 2 explores the social and political role of the descendants of the Prophet in different regional and political contexts. The focus, in Part 3, then shifts to the Prophet and his place in the ideologies and political practice of Muslim nation-states since the early twentieth century. Finally, Part 4 discusses patterns of attachment and reference to the Prophet in processes of social and communal mobilisation and empowerment, and even of attempted statebuilding, in the contemporary Muslim world. The coverage of the different periods and polities could only remain far from exhaustive, but the reader will find contributions on states and countries as distant as Morocco, Albania, Turkey, Egypt, Iraq, Afghanistan, Pakistan, and India.

\section{Empires and Revolutions}

Part 1 highlights a long-term phenomenon of the religious and political sphere which can be traced to the late fifteenth and early sixteenth centuries and remained effective throughout the early modern period. This was the emergence of the Prophet as protector and model for divinely guided rulers and founders of imamates, sultanates, and empires. Marked by the rise of the three large Muslim empires of the Safavids, Ottomans, and Mughals, this period saw dramatic developments taking place both in Europe and in the Muslim world along with an upsurge of eschatological expectations. Shared by Muslims and non-Muslims alike, these have even been labelled as a "millenarian conjuncture" as they affected regions as distant as Portugal and India. ${ }^{5}$ An intensification of the pious attachment to the person of the Prophet, at individual as well as collective levels, can equally be observed in many regions of the Muslim world during that period. ${ }^{6}$ Supported by these widespread messianic sentiments, sultans and emperors set out for conquests of new territories or for the

4 See Laroui, Islam et histoire, 51, 69-9o, and his critical remarks on this all-too-common historiographical one-sidedness, discussed in Riecken, "Abdallah Laroui", 395ff.

5 "Conjoncture millénariste"; see Subrahmanyam, "Du Tage au Gange".

6 Reichmuth, "Aspects of Prophetic Piety". 
reconquest of areas and cities that had for a long time formed part of Christian kingdoms. ${ }^{7}$

These Muslim conquerors who saw their struggles as following the footsteps of the Prophet of Islam presented themselves as renewers of his community and claimed his worldly and spiritual heritage for themselves. In order to reinforce this attachment to the Prophet and to enhance their political legitimation, they encouraged the public veneration of his person and patronised large celebrations of his nativity. In Chapter 1, Gottfried Hagen argues that this cult, under the auspices of the House of Osman, became part of a specific configuration of Islamic religiosity that was centred on the persona of the Prophet. It was mainly informed by literary and calligraphic media (sìra, praise poetry, hilye, mawlid) and by rituals like the display and honouring of the Prophet's relics, such as his mantle and his banner. These performances highlighted Prophetic charisma and promoted emotional expressivity. They invoked the presence of the Prophet's person and promised to lead to salvation by means of spiritual immersion rather than by imitative orthopraxy (although the two certainly could never be neatly distinguished). Ottoman religious and historical scholarship can also largely be seen as serving this image of the charismatic Saviour-Prophet.

Considerably informing this political patronage, devotional practices related to the person of the Prophet were strongly framed by the Sufi brotherhoods whose geographical and social expansion was at its peak during the early modern period. Sufis followed the conquering armies as protectors and spiritual advisors to the soldiers and sultans. The Sufi shaykh Āq Shams al-Dīn (Akşemsettin), spiritual master of Mehmed II, predicted to the sultan the fall of Constantinople (1453) and pointed out to him the tomb of Abū Ayyūb al-Anșārī (Eyüp Sultan), companion of the Prophet, in the vicinity of the Byzantine city; this became the place of the famous sanctuary at the Golden Horn, where the Ottoman sultans would henceforth be girded with the sword of Osman.

The Khalwatiyya brotherhood played an important military as well as cultural role in the Ottoman conquest of the Balkans. ${ }^{8}$ Similarly, the Naqshbandiyya of Central Asia extended to northern India and the Deccan in the wake of the rise of the Mughal dynasty. ${ }^{9}$ In Iran, the Safavid dynasty itself emerged from a Sufi tariqa (pl. țuruq) whose founders claimed Prophetic descent and later passed to Shi'ism. In the Maghrib, the alliance and interplay of Sufism and Sharifism gave birth to the great zāwiyas, some of which would shape the cultural

7 Garcia-Arenal, Messianism and Puritanical Reform.

8 Clayer, Mystiques.

9 Buehler, "Naqshbandiyya in Tīmūrid India"; Green, Indian Sufism. 
and political history of this country throughout the early modern period. ${ }^{10}$ Particularly, the veneration of the ashräf (sing. sharîf) in Morocco was strongly backed by the turuq and became institutionalised in the fifteenth century, at the time of a profound weakness of a ruling dynasty facing Christian offensives against the country's ports and cities. As a result, men of God who regarded themselves as invested with the mission of renewing religion rose up to defend the dār al-isläm. Here, as in the case of the Safavids in Iran, the rise of a new Sharifian dynasty in the sixteenth century enjoyed strong popular and Sufi support and unfolded in a climate of fervent eschatological expectations.

From North Africa and the Middle East to Central Asia and South Asia, Muslim rulers relied on the patronage of Sufi shaykhs and their brotherhoods for the sake of legitimation and for the establishment of Sunni Islam in the conquered regions. Along with the erection of mosques, mausoleums, and Sufi centres (khānqāhs, tekkes, zāwiyas), cults of saints of local or translocal significance would frequently develop. Sainthood was often derived from the doctrine of the cosmic reality of the Prophet as a primordial light giving birth to the world, and as an intercessor for his community. He was thought to extend his blessings through the saints, the "Friends of God" (awliy $\vec{a}^{2}$ Alla $h$ ), as his spiritual representatives. The Prophetic heritage thus came to be shared in Sufi ideology between Prophetic descent and identification with the Prophet through spiritual realisation of his model; two concepts that remained in a close but tense relationship to each other. ${ }^{11}$

The cult of the Prophet and of the saints did not go uncontested. The old debates and polemics that centred around the doctrine of Muhammad's mediation and intercession and the religious practices to which they gave rise had been revived since the fourteenth century, particularly in the circle of Ibn Taymiyya (d. 1328) and his followers. They were now resumed with renewed vigour in the sixteenth and seventeenth centuries by Birgili (or Birgivi) Mehmed Efendī (d. 1573) and his successors, the Kadizadelis, a puritan and anti-Sufi movement which became highly influential in the Ottoman capital as well as in the provinces, especially in Syria. The Kadizadelis engaged in fierce confrontations with their adversaries, and sometimes physically attacked the Sufis and their tekkes. ${ }^{12}$ They contested many of the theosophical and mystical doctrines and practices of the time and advocated a return to the historical

10 Berque, Ulémas, fondateurs, insurgés du Maghreb; Berque, Al-Yousi; Laroui, Les origines sociales et culturelles du nationalisme Marocain, 137; Cornell, Realm of the Saint.

11 Cf. Cornell, Realm of the Saint; Berque, Al-Yousi, 55ff., 87-93.

12 Chelebi, Balance of Truth; Öztürk, "Islamic Orthodoxy"; Zilfi, Politics of Piety; Çavuşoğlu, "The Kādīzādeli Movement". 
model of the Prophet through a strict application of his sunna. Following the long tradition of anti-Sufi writings, they denied the claims of the Sufi shaykhs to charismatic authority and called for respect of the sacred texts alone.

The two further contributions to Part 1, which highlight the significance of the Prophetic model for the revolutionary Islamic movements of the eighteenth and early nineteenth centuries, reflect this tense antagonism between the Sufis and their opponents in religious and political life. Enmity against the Sufi veneration of saints and the Prophet found its most radical and exacerbated expression in the Wahhābī movement in Arabia. ${ }^{13}$ Its view of the Prophet and of Islamic history is discussed by Martin Riexinger in Chapter 2 on the summarised biography of the Prophet titled Mukhtașar sìrat al-rasūl (Short version of the life of the Prophet), written by Muhammad b. 'Abd al-Wahhāb (d. 1792). In his narrative, which is largely based on the Sïra of Ibn Hishām, all episodes which illustrate the superhuman nature of the Prophet have been left out; he retains only those which describe him as an ordinary human being who was not free from error (as demonstrated by the famous story of the "Satanic Verses"). Imitation of him therefore had to be restricted to clearly normative matters. The author passes over all the miraculous events connected with the foretold coming, gestation, and birth of the Prophet, thus undermining the whole doctrine of the "Muhammadan Light" as the principle of creation, one that is celebrated in all the mawlid narratives which were so popular at his time. Even the most outstanding event in the traditional accounts of Muhammad's life, his heavenly ascension ( $\left.m i^{\prime} r a \bar{j}\right)$, is also dealt with only briefly.

The obvious insistence on Muhammad as an ordinary human being is supposed to clear him of any veneration that would tarnish the sole worship of God alone (i.e. the tawhìd al-ulühiyya, the central tenet of Wahhābī ideology). This sira can also be read as an ethical and political programme: it is the Muslims who have now succeeded the prophets in their task to educate and coerce mankind whenever it lapses into idolatry (shirk), and to lead it back to the path of God by re-enacting the Prophetic model. Riexinger finally brings out the cyclical and basically pessimistic view of human history underlying Ibn 'Abd al-Wahhāb's Sìra. It may be added that it appears difficult not to relate this moral pessimism to the turmoil of the author's lifetime, which had overlapped in his early years with Nādir Shāh's stunning military incursions into the Ottoman and Mughal empires.

The anti-Sufism of the Wahhābī emirate of the eighteenth and early nineteenth centuries clearly remained an influential though marginal position in

13 Mouline, Clerics of Islam; Peskes, Muhammad b. 'Abd al-Wahhāb; for Ibn 'Abd al-Wahhāb's links to Syrian Kadizadeli scholars, see Currie, "Kadizadeli Ottoman Scholarship". 
its time. In fact, most contemporaneous Islamic reformist and revolutionary movements in the different parts of the Muslim world were strongly shaped by Sufism and by Sufi brotherhoods active in their regions; even if they shared a good deal of their reformist agenda with the Wahhābīs. ${ }^{14}$ In Chapter 3 , Stefan Reichmuth's comparative overview of these movements highlights the crucial role of their attachment to Prophetic models and proposes to view them as part of a Muslim "Age of Revolutions". They roughly coincided with the revolutionary period in Europe and America but took on their own religious and political dynamics well before being drawn into the confrontation with European and Chinese - imperial expansion. Reichmuth presents in detail four features, widely shared among them, that illustrate the attachment of these movements to the Prophet. They include a strong reliance on Prophetic hadith for their doctrinal positions and their religious practice; an orientation towards Medina and the creation of local memorial landscapes connected with the Prophet and his companions; a programmatic emulation of the Prophet as a source of religious and political mobilisation; and a cultivation of eschatological expectations, including the posing of their leaders as "renewer" (mujaddid) or even as the Mahdī. Taken together with their creativity in developing new models of an Islamic political order for their regions, they add to the profile of a Muslim revolutionary age that would exert a lasting impact on the Muslim world of the nineteenth and twentieth centuries.

\section{Prophetic Descent and Authority}

In Part 2, the political and social role played by the descendants of the Prophet (sayyids, ashräf) in different regions and times is explored by three contributions. Chapter 4, by Jaafar Ben El Haj Soulami, traces out the historical development of the institutionalised body of the Prophetic descendants (niqäbat al-ashräf) in the Maghrib. Although the Mālikì scholars of this region were familiar with the legal framework for the niqāba as part of the caliphal apparatus, which had been largely shaped by the Shāfíi jurist Māwardī (d. 450/1058), the institution did not play any notable role until the Marinid period, when the status of the ashräf was much enhanced by the sultans. Under the Sharifian dynasties the apparatus of the niqāba was much diversified and brought by

14 See e.g. for the Sufi background and reformist polemics of the jihād movement in northern Nigeria, 'Uthmān b. Fūdī, Bayān wujūb al-hijra; Hiskett, Sword of Truth; for the Ṭarīqa Muhammadiyya of Sayyid Aḥmad Brēlvī in northern India, see Gaborieau, Le Mahdi incompris; for the Padris of Sumatra, see Dobbin, Islamic Revivalism. 
some of its most energetic rulers under their close supervision. The legal framework was adapted to the needs of the Sharifian status groups, and the directories of Sharifian families were updated several times amid larger efforts initiated by the sultans. The later centuries also saw a rise of genealogical and historical studies among the Moroccan scholars, who thus responded to the increasing significance of the ashrä $\mathrm{f}$ in the country, and to the need for the protection and control of the membership of this prestigious group, which kept its considerable political potential vis-à-vis the royal court. The account shows in an exemplary way the social and political integration of the ashräf into a Muslim polity of the early modern period that was ruled by a Sharifian dynasty.

In India, in eighteenth-century Delhi, the famous Sufi and poet Mīr Dard (d. 1785), described by Soraya Khodamoradi in Chapter 5 , attempted to conceive of a Sharifian solution to the divisions and sectarian conflicts between Sunnīs and Shīiss, which were regaining strength with the decline and decentralisation of the Mughal Empire. Being of Prophetic descent himself and belonging to circles of the Naqshbandiyya Mujaddidiyya founded by Ahmad Sirhindì (d. 1622), he claimed a revival of the line of the Shīi Imams in the person of his father, the founder of a Sufi tariqa of his own, which he had called "The Pure Muhammadan Path" (Ṭariqa Muhammadiyya Khälișa). Dard's elaborated concept of the tariqa of his father, whose authority was to be founded on both genealogical and spiritual links to the Prophet, was offered by him as a model for the reconciliation of Sunnīs and Shī̄is under this Sufi umbrella. Dard and his father thus posed as bearers of religious renewal and as unifiers of a Muslim community in the grip of a deep political, moral, and religious crisis. Even if this peculiar branch line of the "Muhammadan Path" clearly remained a road not taken by others, it illustrates the enduring self-concept of prominent sayyids who were still able to regard themselves as standing above the sectarian divisions in Islam.

The case of the contemporary "Syndicate of the Descendants of the Prophet" (niqäbat al-ashräf) in Egypt, studied by Catherine Mayeur-Jaouen in Chapter 6, describes a very old institution whose recent history is anchored in the construction of the Egyptian state under Muhammad 'Alī (1805-48). Dissolved after the revolution in 1953, it was re-established in 1991 and became situated together with the headquarters of al-Azhar (mashyakhat al-azhar) and the state institution responsible for fatwas (dār al-iftâ) in a set of three modern buildings in neo-Mamluk style, not far from the old centre of Cairo. Its main activity, the verification of Sharifian genealogies, relies on the established science of genealogy ('ilm al-ansāb). At the same time, it also reinforces the interconnections and the status of a family-oriented Islam in Egypt, which is still strongly territorialised and closely connected with Suf families and activities. 
Its social and religious dimensions locate the niqa aba outside the bureaucratic and political world to which it belongs at first sight. It is part of an Egyptian Islam that defies globalisation and insists on endangered continuities. It can ultimately be identified as an interpretation of the Prophetic intercession that forms the basis of the very constitution of the ashräf as a privileged group - a claim now disputed by Salafism and ignored by a majority of Egyptians.

\section{Modern Nation-States and Ideologies}

Part 3 covers a period of profound political change, ranging from the revolution of the Young Turks, the First World War and the end of the Ottoman caliphate to the birth of the Turkish Republic and the Soviet Union, to the independence movements after the Second World War and to the birth of new nation-states.

Some Turkish accounts of Muhammad's life which appeared in the late nineteenth century had already presented him as a reformer who brought about profound social reforms for the society of his time. By this they attempted to legitimise the reforms initiated by the Ottoman state. Still before the revolution of the Young Turks, the historian Ahmed Refik (d. 1937), trained at the military school, had authored a small work on the military campaigns (ghazawāt) of the Prophet (published in 19o6). Its four chapters are devoted to his four most important battles, which are illustrated with maps and sketches. Miracle stories are either ignored or minimised in this narrative which portrays the Prophet and the companions as embodiments of all the qualities required for a perfect soldier in a modern army. ${ }^{15}$

Representations of the Prophet continued to play an important role in the intellectual debates before and after the First World War. The sacred image of the Prophet that had still prevailed in the nineteenth century gave way under the combined impact of European imperialism and orientalism, to the model of a military and political leader and of a religious and social reformer, which was disseminated by the new printed media and literary genres of the time. Classical accounts of the Prophet were reoriented or rewritten to serve nationalist projects. A famous case was the adaptation of Būṣirì’s famous poem in praise of the Prophet, the "Mantle ode" (Qașidat al-burda), by the Egyptian poet Ahmad Shawqī (d. 1930). His version, titled "The way of the mantle" (Nahj al-burda), was written in 1910 in a country facing Ottoman decline and British occupation. This poem restructures the Burda "into a forceful and eloquent plea for the restoration of the Islamic Ummah based on 'humanistic' concepts

15 Hagen, "The Prophet Muḥammad". 
which he locates in the Classical Arab-Islamic past".16 It became a huge success, especially in its version which was sung by Umm Kulthūm in post-World War II Egypt. ${ }^{17}$

The writing of biographies of the Prophet, which had declined in the nineteenth century, re-emerged in Egypt during the interwar period - but in a complete break with the traditional siras. The aim of these modern biographies was ideological and didactic and was aimed at a broader public. There was no longer any question of miracles or legends, and Muhammad is presented in them as an ingenious human being responding to the needs of his time. This reorientation also responded to a political and cultural disenchantment with Europe and found its strongest expression in Muhammad Husayn Haykal's Hayāt Muhammad (1935). He attempted to recall the genius of the Prophet in order to reconcile the eternal truths of Islam with human reason and with the changing practical demands of modern society. ${ }^{18}$ This trend continued until the 196os, when 'Abd al-Raḥmān al-Sharqāwì's Rasūl al-ḥurriya (The messenger of freedom, published 1962) presented the Prophet as a precursor of Nasserist socialism.

The model of Muhammad as a social and political reformer was also cultivated by Muslim and even Arab Christian Communists who supported the emerging Soviet Union. In Chapter 7 , Renaud Soler follows the career of Bandali Şalībā Jawzì (d. 1942), a Palestinian Orthodox Christian who turned towards Marxism and settled as an academic in Baku, keeping his connections with the Arab Middle East throughout his life and continuing to write in Arabic along with Russian. In his magnum opus, Min tārīkh al-harakāt al-fikriyya fì l-islām (On the history of the intellectual movements in Islam, printed in Jerusalem in 1928), he outlines his views on the life of the Prophet for an Arab readership by integrating him into his Marxist scheme of dialectical materialism. Here, the Prophet appears as an authentic Arab reformer who tried to reduce the existing inequalities of wealth and the oppression of women in his society, and who fought against tribalism without perceiving or being able to touch at the roots of social disorder. As such he sees him as a forerunner of a future socialist order for the Arab and Muslim world, which was further foreshadowed by the revolts of Bābak and the Ismāīilīs and Qarmațians in 'Abbāsid times.

In the period after the Second World War, the Prophet was instrumentalised by the nation-states which had emerged in the meantime. They presented him

\footnotetext{
16 Stetkevych, The Mantle Odes, xiv.

17 First sung in 1946; Fakhreddine, "Umm Kulthūm".

18 Haykal, Hayāt Muhammad. For a critical account of his description of the Prophet, see Johansen, Muhammad Husain Haikal, especially 170-86.
} 
as a model and identity founder for their nationalist and pedagogical projects. Even in the most secular of these states a gradual shift towards a strengthening of their Islamic character can be observed since the 199os, which also touches upon the public status of the figure of the Prophet.

This comes out very clearly in Dilek Sarmis's Chapter 8, on the role of the Prophetic figure in school textbooks and religious education in Turkey. Whereas the figure of the Prophet Muhammad had been overshadowed by that of Mustafa Kemal, who was associated with the Prophetic role by nationalist intellectuals in the 1920s and 1930s, it has markedly increased in visibility in the pedagogical literature since the 1980s. It can be noted that the earlier doctrinal and historical approach to the Prophet has been superseded by his role as a model for citizenship and human exemplarity for the Turkish state. The moral figure of the Prophet became functional for the solution of questions of identity and social conflicts faced by the individual citizen. As an instrument of educational and social engineering, he remains a common identifier for Turkish citizenship. Paradoxically, the moralisation of a modern republican Prophet has also led to a recognition of public rituals connected with his birth (mawlid) and to a revival and institutionalisation of sira studies.

In the case of post-Communist Albania studied by Gianfranco Bria in Chapter 9, the celebration of the Prophetic birthday (mevlud in Albanian) was gradually integrated into the cultural framework of a secular Albanian nationalism. Already since the late Ottoman period, mevlud literature was firmly established as part of the national literary culture. In the interwar period, mevlud celebrations had become an important element of public Islamic piety in a pluralist and confessionalised kingdom, and an emotional and performative medium for Muslim religiosity. The radical socialist secularisation that followed this period virtually wiped out the religious practice of the mevlud and its literary memory. The post-socialist era, still dominated by a socialist heritage of secular rationalism, has seen a state-sponsored revival of the mevlud as a political expression of identity and patriotic belonging to the Albanian nation.

In Chapter 10, Jamal Malik's study of the position of the Prophet in the legal and constitutional framework and its social reality in Pakistan traces the trajectories of laws related to blasphemy in British India, followed by their translation into the Pakistani constitution and penal law against the backdrop of the discussion on the Islamicity of the fledgling state. In the Islamic Republic of Pakistan, the majority of judgements on this issue have been pronounced against non-Muslims and minorities. The atrocious consequences of the public handling of these laws are exemplified with three cases that have caught the attention of the national and international media: the assassination of the 
governor of Punjab in 2011 with the subsequent veneration of his murderer, the lynching of Mashal Khan in early 2017, and the spectacular rise of the religiopolitical party Tehreek-e Labbaik Ya Rasool Allah in late 2017 and 2018. These cases provide some understanding of the struggles between local factions competing for the scarce resources of patronage and public goods, in which the Prophet becomes a major point of reference.

In Chapter 11, David Jordan investigates the changing representation of the Prophet Muhammad in the public discourse of the Iraqi Arab Socialist Bath Party from 1943 till 2003, which underwent a striking increase of its religious expression during and after the First Gulf War. Focussing on the role of the Prophetic figure in Ba'thist ideology and politics throughout this period, Jordan argues that, in the core, the Ba'th regime remained committed to its secular principles till the end but gradually increased the incorporation of the Prophetic heritage into the official political language. The turn towards the use of Islamic traditions and motifs by an Arab nationalist regime can be explained as a strategic attempt to take advantage and remain in control of the general Islamic and religious resurgence that could be observed throughout the Islamic world and beyond since the late 196os. This was a political move that fuelled and promoted this resurgence even further.

\section{Mobilisation, Empowerment, and Social Reform}

Part 4 is dedicated to attempts to claim the Prophet for efforts at social and political mobilisation and reform. If his figure was desacralized by reformist religious currents and by nationalist leaders and their parties like those in Iraq, Syria, and Egypt, a resacralization of social and political life set in from the 1970s onwards which spread throughout the Muslim world. The course of the Iranian Revolution (from 1979), the war against Russian occupation in Afghanistan (1979-89), and the breakdown of the Soviet Union (1991) formed the backdrop to a multifaceted process of social Islamisation and for the proliferation of Islamic educational, missionary, and political movements. These were led by Islamic scholars, preachers, intellectuals, and students, who have increased their public recognition and their political weight in many Muslim countries. The Prophet has once more moved to the centre of the efforts of diverse religious actors for social and religious reform and political empowerment, for militant resistance against foreign powers, and for the establishment of an Islamic state in the turmoil of multisided warfare in the Middle East.

The positivist approach to the life and mission of the Prophet already permeated the writings of the early Muslim reformists of the twentieth century. 
Florian Zemmin (Chapter 12) explores the construction of the Prophet as an ideal religious and social reformer, which was put forward by the Syrian Islamic intellectual Rashīd Riḍa (d. 1935), in his journal al-Manār and in his tremendously successful book titled "The Muhammadan inspiration" (al-Wahy al-muhammadī, first published 1933). Based on a distinction between a true and universal Islamic religion (al-islām al-dīn $\bar{\imath}$ ) and its actual innerworldly manifestations (al-islām al-dunyawī), Rị̣ā attempts to construct Islam as a programme of comprehensive reform in all social and political fields, aiming at the perfection of humans as individuals and collectivities. His representation of a modern Prophet pursued two aims: on the one hand, the emotionally charged figure of the Prophet mediated the salience and practicability of abstract Islamic principles to a wider audience; on the other hand, he served as a role model and lent authority to Riḍa himself, who poses in his writings as a self-styled reformist. Zemmin shows that the debates about religion and modernity and the pedagogical reconstruction of the figures of the prophets as reformist role models were not unique to Islam but can also be found in the contemporary writings of Jewish and Christian intellectuals and theologians. Ridâ's activist view of the Prophet already foreshadows the concept of an individual moral recovery (ișlāh fardī) from contemporary decadence, which would provide the base for a reform of the whole society (ișlähjamáci $)$ and for its immunity against imperialist influence, and which was later developed by the Islamist thinker Sayyid Quṭb (d. 1966).

Rachida Chih, in Chapter 13, discusses the writings and activities of Shaykh Abdessalem Yassine ('Abd al-Salām Yāsīn, d. 2012), founder of the so-called Islamist movement "Justice and Spirituality" (al-'adl wa-l-iḥsān) in Morocco, who claimed for himself the title of "reviver of religion" (mujaddid al-din), predestined to restore the purity of the faith and renew Islamic law. He identified with this role on the basis of his Sharifian and Sufi legacy and set himself the mission of the moral reconstruction of the Muslim mind. This he saw as a preliminary step that would lead to the building of a society defined by Islam. He also founded his own community $\left(\operatorname{jam}_{\bar{a}} \mathrm{a} a\right)$ as a model for this new society. On the basis of the examination of his major work, al-Minhäj al-nabawi (The Prophetic path), Chih analyses Yassine's concept of the Prophetic heritage. Relying on the memoire of a messianic mysticism that has been identifiable in Morocco since the Middle Ages, which he fused with concepts of activist piety borrowed from the Muslim Brotherhood in Egypt, Yassine established himself with this book in the eyes of his followers as an imam predestined to set in motion a great social transformation. This would restore the Islamic community to its original purity by placing it under the direction of an actualised sunna of the Prophet. 
Alix Philippon's Chapter 14 offers a social movement approach to the Sufi organisation which has been at the centre of the anti-blasphemy campaigns over the recent years in Pakistan (discussed already by Malik in Chapter 10 from a more legal and constitutional perspective). The example used for this are the Barelwis, a Sufi and theological movement originating from nineteenthcentury India, which has most loudly proclaimed its love for the Prophet and has posed as a staunch defender of his honour against any attacks. The author describes the figure of the Prophet Muhammad as a symbolic reference point and an "empty signifier" (Laclau) for the negotiation and structuring of social conflicts, and for the articulation of political claims for collective action. After participating in several political alliances of Islamic groups, the Barelwi activists finally succeeded in taking the lead in the protest against the publication of the (in)famous Satanic Verses written by Salman Rushdie. An organisation called "Preservation of the Honour of the Prophetic Message" (Tahaffuz-e Namoos-e Risalat) was founded by them for this purpose. In later times the Barelwis who always struggled for recognition vis-à-vis the other Islamic organised bodies like the Deobandis and the Jama'at al-Islamiyya came to the fore with their calls for a rigorous application of the death penalty for blasphemy. The author describes the background and activities of one of the most active and most successful Barelwi leaders, Pir Afzal Qadri (b. 1953). He is the founder of several religious organisations, and patron of a mass movement, Tehreek-e Labbaik Pakistan (TLP, mentioned above), which has become the main protagonist of these anti-blasphemy campaigns which managed to exert maximum pressure on the Pakistani government and judiciary. It finally took part with considerable success in the nationwide elections of 2018 , by this reasserting the position of the Barelwis in the political landscape of Pakistan.

The different uses of Prophetic images by a wide selection of actors in Afghanistan who were involved in the resistance against the Communist regime in Kabul and the Soviet military invasion between 1978 and 1992 are investigated by Jan-Peter Hartung in Chapter 15. His analysis of rare source materials (mainly in Pashto) shows a considerable variation in the uses of the images of the Prophet that were invoked, depending on the social and educational background of these activists. While urbanised Islamist circles emphasised Muhammad's role as military commander and statesman, those of rural and tribal origins rather stressed his image as the ideal guide to salvation in the hereafter. A closer look into such images in Pashto poetry, classical and contemporary, suggests that both positions seem to have historical antecedents, which reflect distinct ethical frames that are at play in the Pashtun-dominated borderland between Afghanistan and Pakistan. One that resonates well with the urbanised Islamists stresses the princely virtues as an epitome of Pashtunness, 
while the other, reflecting the views of more subaltern rural and tribal actors, emphasises egality as the Pashtun social ideal. Islamic ethics, epitomised in the figure of the Prophet, thus articulates in distinct ways with the different social layers of Pashtun society.

The most recent attempt to create an Islamic caliphate built on the Prophetic model was the so-called Islamic State (IS), which was established in northern Iraq and eastern Syria and whose remnants still linger on in scattered groups of fighters in the Syro-Iraqi borderland and in other regions of the Middle East and North and West Africa. In Chapter 16, Christoph Günther, who has analysed the self-expression of the Is (founded 2013) and its predecessors in Iraq after 2003, highlights the role of the Prophet Muhammad as a major source of self-legitimisation for these and other groups of the Jihādì-Salafì current. He scrutinises several topics and symbols which illustrate the effort of the is to appropriate the Prophetic aura and presence for its own authority. Via texts and songs (anāshìd), and by their highly elaborated propaganda films they frequently refer, directly or indirectly, to the Prophet or to the nascent Muslim community under his leadership. But Günther also argues that, although Is leaders have fiercely claimed to defend pristine Islam and to follow the most exact interpretation of its sources, they hardly engaged intellectually with the sunna itself. The figure of the Prophet has been mainly evoked by them for spectacular actions and for their aesthetics of violence in order to equip their own rule with Prophetic power.

If nothing else, the contributions to this volume may serve to illustrate a Weberian truism about the interplay of economic and political developments with religious and cultural phenomena, which may be conditioned by economic and political processes but may also be relevant for them. ${ }^{19}$ This interplay includes pious as well as strategic patterns of identification with the Prophet. Each case has, of course, to be observed and closely assessed in order to clarify its specific constellation of factors. Collective attachment to the Prophet and political strategies pursued by leaders, individuals, and groups seem to reinforce each other in several ways in the described case studies, which expose the contradictions and weaknesses of the respective political and legal systems. The Prophet comes out in them as a larger-than-life symbol of sociopolitical representation and identity (Chapter 9), as the model of an

19 Weber, “'Objektivität' sozialwissenschaftlicher Erkenntnis", 202-6, defines the interdependences between economic and cultural phenomena as an object of the social and economic sciences; see also Swedberg and Ageval, Max Weber Dictionary, 73; Giddens, "Marx, Weber and the Development of Capitalism", 297. The transfer of this model to political science can be found e.g. with De Grazia, Political Behavior, 66, who divides its objects into "politics, the politically relevant, and the politically conditioned". 
ideal reformer (Chapter 12) or of a civilised citizen (Chapter 8), as ancestor of the leader and supra-confessional integration figure (Chapter 11), with his honour serving as a rallying cry against internal enemies (Chapters 10 and 14). He may also reinforce princely or egalitarian values in urban or rural settings (Chapter 15), offer a model for a future utopian society under an ideal leader (Chapter 13), or enhance the power of a self-acclaimed caliphate (Chapter 16). In many of these exemplary cases, his presence and authority have been evoked with diverse and sometimes quite innovative forms of communication and in novel organisational settings.

\section{Conclusion}

The resurgence of Islam which unfolded since the late 1970s has been such that even states that had pursued a policy of secularisation could not fail to refer to religion in order to legitimise their authority. The Prophet, who had been emptied to a large extent of his spiritual dimension in public and political life, was then invoked again as an eschatological figure. The case study of Iraq (Chapter 11) provides perhaps the most telling example of the radical ideological turn of a secular government towards the revival of the figure of the Prophet as intercessor and saviour since the war against Iran in the 1980s and the humanitarian crisis provoked by the Gulf War in the 1990s, with the president posing as a descendant of the Prophet and accusing Imam Khomeini (himself also a sayyid) to be an enemy of Islam.

It appears striking that the actors of the recent Islamic mobilisation movements quite often relate themselves in their identification with the Prophet to the revolutionary Islamic movements of the eighteenth and early nineteenth centuries in their home regions and beyond, whether to those in Arabia, West Africa, or in South and Central Asia (see Chapter 3). Or they revive older patterns of religious doctrine and expectation along Prophetic or Imamic lines, as in the Islamic Republic of Iran or in the case of Morocco (see Chapter 13). Islamological research has often let itself be taken in by this historical selfidentification of Islamist actors, without giving sufficient attention to the contemporary challenges that they have been facing together with their societies, and to the unmistakably modern traits of their movements.

But all of the contemporary Islamic movements certainly fit into a general historical trend that can be observed throughout the early modern and modern period. It consists in the growing importance, from late medieval times onwards, of the figure of the Prophet, in learned religious circles as well as in popular piety. This has been supported and encouraged by the political elites 
who, from the fifteenth century onwards, made their links with the Prophet a source of legitimation for their own power.

The figure of the Prophet, which throughout history oscillated between human and superhuman dimensions, has been constantly reappropriated under different modes of reference. This can be related to its eschatological quality, which - as argued in the general introduction - not only invites expectations regarding the end of the world but also beliefs in a salvation already unfolding in the present. In imperial times, sultans and emperors displayed their ethical, spiritual, and charismatic links with the Prophet as a source of legitimation and a promise of universal peace and justice (as seen in Chapter 1 for the Ottomans). In the revolutionary movements of the eighteenth and early nineteenth centuries the Prophet was referred to as the founder of the original and authentic Muslim community, and as a model of action. In the times of the nationalist movements and the struggles for independence, he was presented as an ideal head of state, a reformer of his society, a source of law and social order, and even as a guardian of Muslim identity and culture. Therefore, his presence has not diminished, neither with modernity nor with the processes of secularisation which have unfolded in most Muslim countries. The explorative studies of the diverse political representations of the Prophet, which have been collected in this volume, bring out the impact of both secularisation and sacralisation on the Prophetic model. They reveal a process full of tensions between these two poles, and an interaction of pious attachment and strategic ploys, which has emerged with full vigour in the hardening of Sunnī-Shīì relations, and in an increasingly globalised struggle over the control of the image of the Prophet. One can only speculate about the consequences that this political instrumentalisation will have for Prophetic piety itself.

\section{Bibliography}

Berque, J. Al-Yousi. Problèmes de la culture Marocaine au XVII ème siècle, Paris, Mouton, $195^{8}$.

Berque, J. Ulémas, fondateurs, insurgés du Maghreb, XVII e siècle, Paris, Sindbad, 1982.

Buehler, A. "The Naqshbandiyya in Tīmūrid India: The Central Asian Legacy", Journal of Islamic Studies 7/2 (1996), 208-28.

Çavuşoğlu, S. "The Kādīzādeli Movement: An Attempt of şeri'at-Minded Reform in the Ottoman Empire", PhD diss., Princeton University, 1990.

Chelebi, K. The Balance of Truth, trans. G. L. Lewis, London, Allen and Unwin, 1957.

Clayer, N. Mystiques, Etat et société. Les Halvetis dans l'aire balkanique de la fin du $X V^{e}$ siècle à nos jours, Leiden, Brill, 1994. 
Cornell, V. Realm of the Saint: Power and Authority in Moroccan Sufism, Austin, Texas University Press, 1998.

Currie, J. J. "Kadizadeli Ottoman Scholarship, Muḥammad Ibn 'Abd al-Wahhāb and the Rise of the Saudi State", Journal of Islamic Studies 26/3 (2015), 265-88.

De Grazia, A. Political Behavior, New York, Free Press, 1965.

Dobbin, C. Islamic Revivalism in a Changing Peasant Economy: Central Sumatra, 17841847, London, Routledge, 2017 [1983].

Fakhreddine, H. "Umm Kulthūm Sings Aḥmad Shawqī's Nahjal-Burdah: A Spiritualization of Polemics", Culture Critique 1/2 (2009), 1-13.

Fūdī, 'Uthmān b. Bayān wujūb al-hïra 'alā l-'ibād, ed. and trans. F. H. El Masri, Khartoum, Khartoum University Press, 1978.

Gaborieau, M. Le Mahdi incompris. Sayyid Ahmad Barelwî (1786-1831) et le millénarisme en Inde, Paris, CNRs Éditions, 2010.

Garcia-Arenal, M. Messianism and Puritanical Reform: Mahdis of the Muslim West, Leiden, Brill, 2006.

Giddens, A. "Marx, Weber and the Development of Capitalism", Sociology 4/3 (1970), 289-310.

Green, N. Indian Sufism since the Seventeen Century, Saints, Books, and Empires in the Muslim Deccan, London, Routledge, 2006.

Hagen, G. "The Prophet Muhammad as an Exemplar in War: Ottoman Views on the Eve of World War I", New Perspectives on Turkey 22 (2000), 145-72.

Haykal, M. Hayāt Muhammad, Cairo, Maṭba'at Miṣr, 1935.

Hiskett, M. The Sword of Truth: The Life and Times of the Shehu Usuman dan Fodio, Evanston, Northwestern University Press, 1994.

Johansen, B. Muhammad Husain Haikal: Europa und der Orient im Weltbild eines ägyptischen Liberalen, Wiesbaden, Steiner, 1967.

Laroui, A. Les origines sociales et culturelles du nationalisme Marocain, Paris, La Découverte, 1977.

Laroui, A. Islam et histoire. Essai d'épistémologie, Paris, Flammarion, 1999.

Mouline, N. The Clerics of Islam: Religious Authority and Political Power in Saudi Arabia, New Haven, Yale University Press, 2014.

Öztürk, N. "Islamic Orthodoxy among the Ottomans in the Seventeenth Century with Special Reference to the Qādī-Zāde Movement”, PhD diss., University of Edinburgh, 1981.

Peskes, E. Muhammad b. 'Abd al-Wahhāb (1703-1792) im Widerstreit. Untersuchungen zur Rekonstruktion der Frühgeschichte der Wahhābiyya, Stuttgart, Steiner, 1993.

Reichmuth, R. "Aspects of Prophetic Piety in the Early Modern Period", Archives des Sciences Sociales des Religions 178 (2017), 129-50.

Riecken, N. "Abdallah Laroui and the Location of History: An Intellectual History", PhD diss., Free University of Berlin, 2013. 
Stetkevych, S. The Mantle Odes: Arabic Praise Poems to the Prophet Muhammad, Bloomington, Indiana University Press, 2010.

Subrahmanyam, S. "Du Tage au Gange au XVI e siècle: une conjoncture millénariste à l'échelle eurasiatique", Annales 1 (Jan.-Feb. 2001), 51-84.

Swedberg, R., and O. Ageval. The Max Weber Dictionary: Key Words and Concepts, Stanford, Stanford University Press, 2005.

Weber, M. “Die 'Objektivität' sozialwissenschaftlicher Erkenntnis”, in J. Winkelmann, ed., Soziologie. Weltgeschichtliche Analysen. Politik, Stuttgart, Kröner 1968, 186-262. [First published as "Die 'Objektivität' sozialwissenschaftlicher und sozialpolitischer Erkenntnisse", Archiv für Sozialwissenschaft und Sozialpolitik 19/1 (1904), 24-87.]

Zilf, M. The Politics of Piety: The Ottoman Ulema in the Postclassical Age (1600-1800), Minneapolis, Bibliotheca Islamica, 1988. 